\title{
INFLUENCE OF FIELD SLOPE AND COFFEE PLANTATION AGE ON THE PHYSICAL PROPERTIES OF A RED-YELLOW LATOSOL $^{(1)}$
}

\author{
Piero Iori ${ }^{(2)}$, Moacir de Souza Dias Junior ${ }^{(3)}$, Ayodele Ebenezer Ajayi ${ }^{(4)}$, Paulo Tácito \\ Gontijo Guimarães ${ }^{(5)} \&$ Áureo Aparecido Abreu Júnior ${ }^{(6)}$
}

\begin{abstract}
SUMMARY
In modern agriculture, several factors cause changes in the soil physical properties. The time of establishment of a crop (plantation age) and the slope are examples of factors that moderate the impact of mechanized operations on the soil structure. The objective of this study was to analyze the effect of machinery traffic on the physical properties of a Red-Yellow Latosol under coffee plantations with different ages $(2,7,18$, and 33 years) and slope positions (3, 9 and $15 \%)$. Samples were collected from three positions between coffee rows (lower wheel track, interrow and upper wheel track) and at two depths (surface layer and sub-surface). Changes in the total porosity, macroporosity, microporosity, organic matter, bulk density, and aggregate stability were investigated. Our results showed that the slope influenced the organic matter content, microporosity and aggregate stability. The soil samples under the inter-row were minimally damaged in their structure, compared to those from under the lower and upper wheel track, while the structure was better preserved under the lower than the upper track. The time since the establishment of the crop, i.e., the plantation age, was the main factor determining the extent of structural degradation in the coffee plantation.
\end{abstract}

Index terms: agricultural traffic, Coffea arabica L., soil degradation, aggregate stability.

\footnotetext{
(1) Part of the PhD thesis of the first author, Soil Science Post Graduation Course, Federal University of Lavras. Received for publication on February 26, 2013 and approved on September 5, 2013.

(2) Professor, Universidade Estadual Paulista "Júlio de Mesquita Filho" - UNESP, Unidade de Registro. Av. Nelson Brihi Badur, 430, Tupy Village. CEP 11900-000 Registro (SP), Brazil. E-mail: pieroiori@hotmail.com

(3) Professor, Department of Soil Science, Federal University of Lavras - UFLA. Postal Box 3037. CEP 37200-000 Lavras (MG), Brazil. E-mail: msouzadj@dcs.ufla.br

(4) Professor, Soil, Water and Environment Division, Department of Agricultural and Environmental Engineering, Federal University of Technology, Akure, Nigeria. E-mail: ayo.ajayi@gmail.com

(5) Researcher, Empresa de Pesquisa Agropecuária de Minas Gerais - EPAMIG, South of Minas Regional, UFLA. E-mail: paulotgg@epamig.br

(6) Forest engineer student, Department of Soil Science, UFLA. E-mail: aureoabreujr@hotmail.com
} 


\title{
RESUMO: INFLUENCIA DA DECLIVIDADE DO SOLO E DO TEMPO DE CULTIVO DE CAFÉ NAS PROPRIEDADES FÍSICAS DE UM LATOSSOLO VERMELHO-AMARELO
}

\begin{abstract}
Vários fatores causam alterações nas propriedades físicas do solo na agricultura moderna. O tempo de cultivo da cultura e a inclinação da área cultivada são exemplos de fatores que podem influenciar, bem como prejudicar, a estrutura do solo. O objetivo deste estudo foi analisar em plantações de café com diferentes idades de cultivo e com diferentes declividades na entrelinha, o efeito do tráfego de máquinas sobre as propriedades físicas do solo. O estudo foi desenvolvido em um Latossolo Vermelho-Amarelo. Selecionaram-se plantações de café com tempos de cultivo de 2, 7, 18 e 33 anos. Nessas plantações, foram selecionadas áreas (entrelinha do café) com inclinação lateral de 3, 9 e $15 \%$. O solo foi amostrado em três posições na entrelinha do café: linha de tráfego de baixo, linha de tráfego de cima e entre as linhas de tráfego (entrelinha). Amostras de solo foram coletadas em duas camadas (superficial $e$ subsuperficial). As propriedades investigadas foram: porosidade total, macroporosidade, microporosidade, matéria orgânica, densidade e estabilidade de agregados. A declividade da entrelinha do cafeeiro influenciou a matéria orgânica e algumas propriedades físicas do solo, como microporosidade e estabilidade de agregados. As amostras na entrelinha (entre as linhas de tráfego) foram as que apresentaram os melhores resultados em termos de preservação da estrutura do solo, em relação às amostras das linhas de tráfegos (de baixo e de cima); as amostras da linha de tráfego de baixo evidenciaram melhores resultados em termos de preservação da estrutura do solo do que a linha de tráfego de cima. Observou-se que o tempo de cultivo da cultura foi o principal fator que interferiu na degradação estrutural dos solos na cultura do café.
\end{abstract}

Termos de indexação: Coffea arabica L., degradação do solo, estabilidade de agregados, tráfego agrícola.

\section{INTRODUCTION}

In the recent past, the agricultural system of Brazil has achieved remarkable progress, thereby contributing significantly to the nation's economic development, due to increasing mechanization. The trend is likely to continue, particularly in coffee cultivation, which currently ranks fifth in agribusiness exports, contributing with US $\$ 8.7$ billion to the Brazilian economy (Brasil, 2012). Most of the commercial coffee farms are located in the southern part of the State of Minas Gerais, known as the largest coffee-producing area in the country (Rangel et al., 2008). It is noteworthy that while agricultural mechanization raised the output from Brazilian agriculture, it also caused remarkable soil structure degradation (Silva et al., 2009). In the coffee management in Brazil, all production stages from weeding and fertilizer application to harvesting are fully or partially mechanized. In these operations, the narrow strips of land between the coffee tree rows are repeatedly subjected to machinery and equipment traffic, thereby increasing their susceptibility to soil compaction. This problem is exacerbated in older coffee plantations.

Soil compaction induced by high traffic intensity can damage the soil structure, thereby reducing the potential yield of coffee plantations (Gontijo et al., 2008). Several soil-dependent conditions can exacerbate the changes in soil physical properties due to agricultural traffic. For example, machinery traffic in coffee plantations under inadequate soil moisture conditions can affect the soil (Miranda et al., 2003). In addition to the soil moisture conditions, the gradient of the farmland (slope) influences the effect of machinery traffic on the soil physical and mechanical properties. Jamshidi et al. (2008) noted that in hilly terrain the load distribution between the tires is uneven, exposing the soil to a higher peak dynamic load. Najafi et al. (2009) also found that the slope influences the surface impact of vehicle wheels even at unchanged traffic intensity. They further mentioned that during machine slippage in steep terrain, the load is applied unevenly on the revolving axis, thus the impact on the ground under this axis changes. Similarly, Krag et al. (1986) found that during the harvesting of timber, the slope moderates stress distribution. They reported that the effects were most pronounced when the slope was 20 $\%$ and higher.

In this study, our hypothesis is that the slope of coffee plantations influences the location of the center of gravity of operating machinery and equipment, resulting in differentiated stress distribution and impact on the soil under a given machine axis and along the wheel track. Since the plantation age can exacerbate this effect due to the residual stress effect on the trafficked area, the objective of this study was to analyze the effect of machinery traffic on the physical properties of a clayey Red-Yellow Latosol under coffee on different slopes and with varied plantation ages. 


\section{MATERIAL AND METHODS}

The study was conducted in coffee plantations in Três Pontas, a county in the South of Minas Gerais, Brazil (24 $26^{\prime}$ S; $47^{\circ} 49^{\prime} \mathrm{W}^{\prime} ; 905 \mathrm{~m}$ asl). The relief of this region is predominantly undulating. The climate, according to Köppen, is Cwa, i.e., tropical highland, with an average annual temperature of about $18^{\circ} \mathrm{C}$. The average annual rainfall is $1,300 \mathrm{~mm}$, with the highest rainfall concentrations between December and February. The soil of the study area was classified as clayey texture Red-Yellow Latosol (Oxisol) (Embrapa, 2006), with $510 \mathrm{~g} \mathrm{~kg}^{-1}$ clay, $200 \mathrm{~g} \mathrm{~kg}^{-1}$ sand and $290 \mathrm{~g} \mathrm{~kg}^{-1}$ silt, and a particle density of $2.62 \mathrm{Mg} \mathrm{m}^{-3}$.

According to farm records, prior to the installation of the coffee plantations, the soil was disk-plowed to a depth of $40 \mathrm{~cm}$ and thereafter harrowed. All equipment used in the coffee management was pulled by a Massey Ferguson 265 tractor (approximate mass 3,940 kg). The implements for the farming operations and their traffic frequency were a fertilizer machine (approximate mass $210 \mathrm{~kg}$, three passes per year), a spray jet Arbus 400 Jacto (capacity 400 L, mass $230 \mathrm{~kg}$, three passes per year), a Kamaq mower (mass $340 \mathrm{~kg}$, three passes per year) and the spray jet $\mathrm{PH}$ 400 (capacity $400 \mathrm{~L}$, mass $210 \mathrm{~kg}$, two passes per year). The total number of annual passings along each wheel track was 11 . Weeds were controlled by mechanical mowing and herbicide application (twice a year January and March). Fungicide was applied in December and February to control leaf rust and brown eye spot. The area was fertilized three times a year (November, January and March) with $150 \mathrm{~g}$ per plant of 20:05:20 N-P-K fertilizer, totalizing $450 \mathrm{~g}$ per plant and per year. The coffee yield from the plantation varied between 30 and 40 bags per ha.

Samples were collected from coffee plantations with different ages: 2 years old (planted in 2008 at a spacing of $3.5 \times 0.7 \mathrm{~m}$ - Cultivar Mundo Novo), 7 years old (planted in 2003, spacing $3.5 \times 0.9 \mathrm{~m}$ - Cultivar Paraíso MG), 18 years old (planted in 1992, spacing $3.5 \times 1.0 \mathrm{~m}$ - Cultivar Mundo Novo) and 33 years old (planted in 1977; spacing 3.5 ×2.0 m - Cultivar Catuaí Amarelo). In the plantations, areas with slopes of 3, 9 and $15 \%(\mathrm{~S})$ and three traffic- related positions in the coffee row: lower track (L), inter-row (I) and upper track (U) (Figure 1) and two layers (D): 0.00-0.03 $\mathrm{m}$ (surface layer) and 0.15-0.18 m (sub-surface) were sampled. Thus, a total of 72 samples were collected: four plantation ages/establishment times $\times$ three slopes $\times$ three traffic - related positions $\times$ two depths), with three replications, totaling 216 soil samples.

Representative soil, sampled according to the above criteria, was used for physical characterizations, as described below. The texture was determined by the pipette method (Day, 1965). Particle density was determined by the pycnometer method (Blake \& Hartge, 1986a), bulk density by the method of Blake
\& Hartge (1986b) and total porosity (TP) was calculated using the expression:

$$
T P=\left[1-\left(B D \cdot P D^{-1}\right)\right] 100
$$

where TP: total porosity $\left(\mathrm{m}^{3} \mathrm{~m}^{-3}\right)$, PD: particle density $\left(\mathrm{Mg} \mathrm{m}^{-3}\right)$ and BD: bulk density $\left(\mathrm{Mg} \mathrm{m}^{-3}\right)$. Microporosity (Mi) was determined from samples equilibrated at $-6 \mathrm{kPa}$ (Embrapa, 1997) and macroporosity (Ma) was determined based on the expression:

$$
M a=T P-M i
$$

where Ma: macroporosity $\left(\mathrm{m}^{3} \mathrm{~m}^{-3}\right)$, TP: total porosity $\left(\mathrm{m}^{3} \mathrm{~m}^{-3}\right)$ and Mi: microporosity $\left(\mathrm{m}^{3} \mathrm{~m}^{-3}\right)$. Organic matter (OM) was analyzed according to standard procedures (Embrapa, 1997) and was determined using the wet combustion method. Aggregate stability was determined by wet screening, with a set of sieves $(2,1$, $0.5,0.25$, and $0.105 \mathrm{~mm}$ ), and the mean geometric diameter (MGD) determined according to Schaller \& Stockinger (1953). The soil property data were initially subjected to analysis of variance (ANOVA), and if the F-test identified significant differences at $5 \%$, the averages were grouped by Scott- Knott criteria using SISVAR computer software (Ferreira, 2000).

\section{RESULTS AND DISCUSSION}

Table 1 presents the ' $F$ ' values in the ANOVA of the parameters: organic matter $(\mathrm{OM})$, total porosity (TP), macroporosity (Ma), microporosity (Mi), bulk density (BD) and the mean geometric diameter (MGD) in response to the effects factors: Years of establishment/plantation age (A), land slope (S), trafficrelated sampling position (P) and sampling depth (D). The results showed that the factors $\mathrm{A}$ and $\mathrm{P}$ were significant at all levels for all studied variables, as shown by the high ' $F$ ' values (Table 1 ). The effect of the sampling depth was not significant for TP, while the slope factor was significant for Mi and MGD. The level of significance of each factor was different for the six studied variables. The age of the coffee plantation was the most important factor affecting TP and BD. Depth was the factor that most affected $\mathrm{OM}$ and MGD. For Ma and Mi, the sampling position was most relevant.

The effect of the establishment times on $\mathrm{OM}$ differed significantly from each other (Table 2), in the order: $18>7>2>33$ years old. In the early years of coffee cultivation, OM contents were low due to crop establishment. As the coffee trees grow older, vegetation is deposited on the soil surface due to the weed management, increasing $\mathrm{OM}$ contents. However, the increased vegetation cover inhibits the growth/ development of weeds. Thus, there will be a higher rate of OM consumption by the coffee plants with no fresh OM input (due to stunted growth of fresh weed), causing a net decrease in the soil OM content. The OM contents were highest in the plane areas 
(slope $=3 \%$ ), while steeper areas (slope $=9$ and $15 \%$ ) had similar, but lower values. The higher OM accumulation in the plane areas could be explained by the minimal soil erosion, where consequently less OM was lost. The steeper terrains (9 and $15 \%$ ) were affected by erosion and the consequent nutrient loss. Different OM contents were found at the three distinct positions, with the highest value under the lower track, followed by inter-row and upper track positions.
These results disagree with those of Gontijo et al. (2008), who found similar OM contents under interrows and wheel tracks. However, aside from not specifying the sampled position of the tracks (lower or upper track), these authors worked with a single slope. The higher OM contents under the lower track in this study can be associated with crop residue accumulation at these points in the plantation. We observed significant differences in OM contents

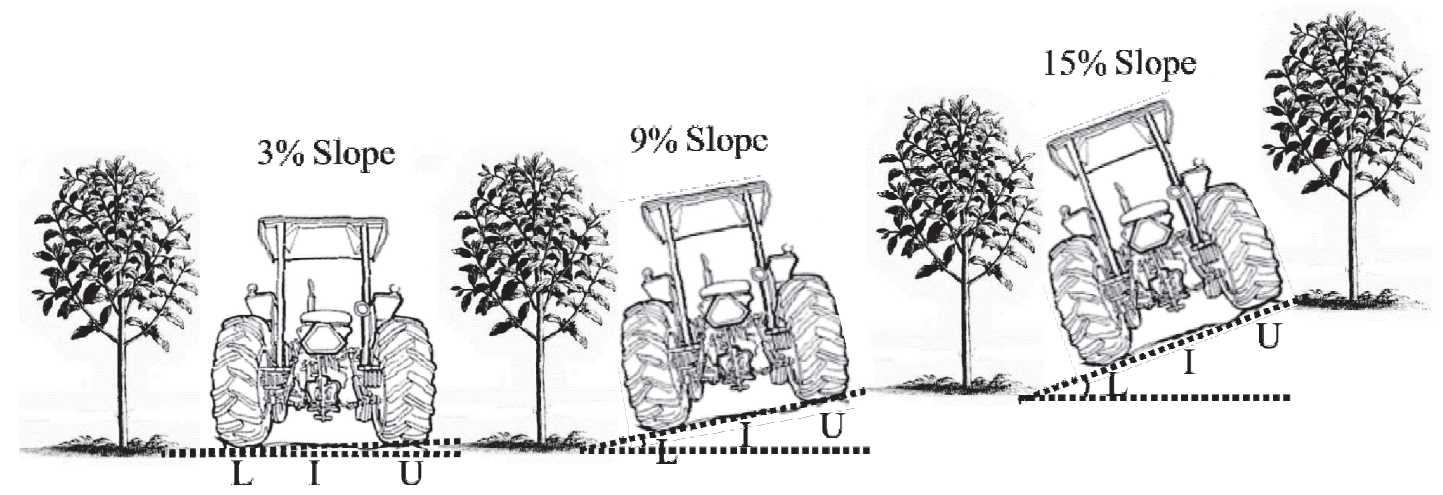

Figure 1. Schematic representation of the sampling points in the coffee row with three slopes (3,9 and $15 \%)$. L: lower track, I: inter-row and U: upper track.

Table 1. ' $\mathrm{F}$ ' values in the analysis of variance for organic matter (OM), total porosity (TP), macroporosity (Ma), microporosity (Mi), bulk density (BD) and aggregate stability by mean geometric diameter (MGD) for different ages of the coffee plantation (A), slopes (S), sampling location (L) and depth (D) in a RedYellow Latosol

\begin{tabular}{|c|c|c|c|c|c|c|c|}
\hline Source of variation & DF & OM & TP & Ma & Mi & BD & MGD \\
\hline $\mathrm{A}$ & 3 & $81.8^{* *}$ & $40.8^{* *}$ & $10.9^{* *}$ & $33.0 * *$ & $36.7 * *$ & $33.7^{* *}$ \\
\hline Error (a) & 8 & & & & & & \\
\hline $\mathrm{S}$ & 2 & $7.3^{*}$ & $0.4^{\mathrm{NS}}$ & $3.0^{\mathrm{NS}}$ & $5.4^{*}$ & $0.4^{\mathrm{NS}}$ & $24.0^{* *}$ \\
\hline $\mathrm{A} \times \mathrm{S}$ & 6 & $18.2^{* *}$ & $1.1^{\mathrm{NS}}$ & $3.3^{\mathrm{NS}}$ & $7.7^{*}$ & $0.9^{\mathrm{NS}}$ & $24.4^{* *}$ \\
\hline Error (b) & 6 & & & & & & \\
\hline $\mathrm{L}$ & 2 & $24.4^{* *}$ & $17.0 * *$ & $30.2^{* *}$ & $50.2^{* *}$ & $28.7 * *$ & $87.5^{* *}$ \\
\hline $\mathrm{L} \times \mathrm{A}$ & 6 & $11.4^{* *}$ & $3.3^{\mathrm{NS}}$ & $5.4^{* *}$ & $5.8^{*}$ & $4.5^{*}$ & $59.2^{* *}$ \\
\hline $\mathrm{L} \times \mathrm{S}$ & 4 & $10.1^{* *}$ & $1.6^{\mathrm{NS}}$ & $1.5^{\mathrm{NS}}$ & $9.6^{* *}$ & $1.7^{\mathrm{NS}}$ & $18.6^{* *}$ \\
\hline $\mathrm{L} \times \mathrm{A} \times \mathrm{S}$ & 12 & $4.5^{*}$ & $1.0^{\mathrm{NS}}$ & $2.1^{\mathrm{NS}}$ & $16.9^{* *}$ & $1.1^{\mathrm{NS}}$ & $33.0 * *$ \\
\hline Error (c) & 6 & & & & & & \\
\hline $\mathrm{D}$ & 1 & $2013^{* *}$ & $0.4^{\mathrm{NS}}$ & $11.5^{* *}$ & $28.4^{* *}$ & $9.3^{* *}$ & $200 * *$ \\
\hline $\mathrm{D} \times \mathrm{A}$ & 3 & $47.0 * *$ & $5.0 * *$ & $3.6^{*}$ & $2.4^{\mathrm{NS}}$ & $2.4^{\mathrm{NS}}$ & $3.0^{*}$ \\
\hline $\mathrm{D} \times \mathrm{S}$ & 2 & $4.2^{*}$ & $0.6^{\mathrm{NS}}$ & $0.4^{\mathrm{NS}}$ & $4.2^{*}$ & $0.4^{\mathrm{NS}}$ & $0.7^{\mathrm{NS}}$ \\
\hline $\mathrm{D} \times \mathrm{L}$ & 2 & $13.4^{* *}$ & $15.7 * *$ & $11.8^{* *}$ & $1.7^{\mathrm{NS}}$ & $9.9 * *$ & $2.3^{\mathrm{NS}}$ \\
\hline $\mathrm{D} \times \mathrm{A} \times \mathrm{S}$ & 6 & $12.8^{* * *}$ & $1.5^{\mathrm{NS}}$ & $0.8^{\mathrm{NS}}$ & $1.2^{\mathrm{NS}}$ & $1.5^{\mathrm{NS}}$ & $13.2^{* *}$ \\
\hline $\mathrm{D} \times \mathrm{A} \times \mathrm{L}$ & 6 & $2.1^{\mathrm{NS}}$ & $1.9^{\mathrm{NS}}$ & $1.7^{\mathrm{NS}}$ & $3.2^{* *}$ & $2.7^{*}$ & $15.2^{* *}$ \\
\hline $\mathrm{D} \times \mathrm{S} \times \mathrm{L}$ & 4 & $7.6^{* *}$ & $0.2^{\mathrm{NS}}$ & $1.8^{\mathrm{NS}}$ & $4.0 * *$ & $0.4^{\mathrm{NS}}$ & $9.8^{* *}$ \\
\hline $\mathrm{D} \times \mathrm{A} \times \mathrm{S} \times \mathrm{L}$ & 12 & $2.7 * *$ & $3.2^{* *}$ & $1.6^{\mathrm{NS}}$ & $1.3^{\mathrm{NS}}$ & $3.1^{* *}$ & $7.6^{* *}$ \\
\hline Error (d) & 124 & & & & & & \\
\hline $\mathrm{CV}$ (a) \% & & 8.5 & 5.0 & 25.2 & 4.5 & 6.0 & 6.1 \\
\hline $\mathrm{CV}$ (b) \% & & 9.0 & 6.2 & 20.0 & 4.1 & 6.6 & 4.9 \\
\hline $\mathrm{CV}$ (c) \% & & 7.5 & 6.5 & 21.4 & 2.2 & 6.5 & 5.7 \\
\hline $\mathrm{CV}$ (d) \% & & 9.5 & 4.4 & 21.4 & 4.8 & 4.7 & 8.1 \\
\hline
\end{tabular}

DF: degrees of freedom; CV: coefficient of variation. ${ }^{* *}$ and $*$ : significant at 1 and $5 \%$, respectively; ${ }^{\text {NS}}$ : not significant. 
Table 2. Mean values of organic matter (OM), total porosity (TP), macroporosity (Ma), microporosity (Mi), bulk density (BD) and aggregate stability by mean geometric diameter (MGD) for different ages of the coffee plantation (A), slopes (S), sampling locations (L) and depths (D) in a Red-Yellow Latosol

\begin{tabular}{|c|c|c|c|c|c|c|}
\hline Factor level & OM & TP & Ma & Mi & BD & MGD \\
\hline & $\mathrm{g} \mathrm{kg}^{-1}$ & 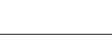 & $\mathrm{m}^{3} \mathrm{~m}^{-3}$ & & $\mathrm{Mg} \mathrm{m}^{-3}$ & $\mathrm{~mm}$ \\
\hline \multicolumn{7}{|l|}{ A (Years) } \\
\hline 2 & $34.1 \mathrm{C}$ & $0.51 \mathrm{C}$ & $0.14 \mathrm{~B}$ & $0.37 \mathrm{~B}$ & $1.28 \mathrm{~B}$ & $3.59 \mathrm{C}$ \\
\hline 7 & $36.9 \mathrm{~B}$ & $0.52 \mathrm{~B}$ & $0.14 \mathrm{~B}$ & $0.38 \mathrm{~A}$ & $1.22 \mathrm{C}$ & $3.83 \mathrm{~B}$ \\
\hline 18 & $40.0 \mathrm{~A}$ & $0.55 \mathrm{~A}$ & $0.18 \mathrm{~A}$ & $0.37 \mathrm{~B}$ & $1.19 \mathrm{C}$ & $3.91 \mathrm{~B}$ \\
\hline 33 & $31.3 \mathrm{D}$ & $0.50 \mathrm{D}$ & $0.15 \mathrm{~B}$ & $0.35 \mathrm{C}$ & $1.33 \mathrm{~A}$ & $4.03 \mathrm{~A}$ \\
\hline \multicolumn{7}{|l|}{ S (\%) } \\
\hline 3 & $36.7 \mathrm{~A}$ & $0.52 \mathrm{~A}$ & $0.15 \mathrm{~A}$ & $0.37 \mathrm{~A}$ & $1.26 \mathrm{~A}$ & $3.95 \mathrm{~A}$ \\
\hline 9 & $35.1 \mathrm{~B}$ & $0.52 \mathrm{~A}$ & $0.16 \mathrm{~A}$ & $0.36 \mathrm{~A}$ & $1.25 \mathrm{~A}$ & $3.73 \mathrm{C}$ \\
\hline 15 & $34.8 \mathrm{~B}$ & $0.52 \mathrm{~A}$ & $0.15 \mathrm{~A}$ & $0.37 \mathrm{~A}$ & $1.26 \mathrm{~A}$ & $3.84 \mathrm{~B}$ \\
\hline \multicolumn{7}{|l|}{$\mathrm{L}$} \\
\hline Upper track & $34.1 \mathrm{C}$ & $0.51 \mathrm{~B}$ & $0.14 \mathrm{~B}$ & $0.37 \mathrm{~B}$ & $1.29 \mathrm{~A}$ & $3.60 \mathrm{C}$ \\
\hline Inter-row & $35.4 \mathrm{~B}$ & $0.54 \mathrm{~A}$ & $0.18 \mathrm{~A}$ & $0.36 \mathrm{C}$ & $1.20 \mathrm{~B}$ & $4.08 \mathrm{~A}$ \\
\hline Lower track & $37.2 \mathrm{~A}$ & $0.51 \mathrm{~B}$ & $0.14 \mathrm{~B}$ & $0.38 \mathrm{~A}$ & $1.28 \mathrm{~A}$ & $3.84 \mathrm{~B}$ \\
\hline \multicolumn{7}{|l|}{ D } \\
\hline Surface layer & $45.8 \mathrm{~A}$ & $0.52 \mathrm{~A}$ & $0.14 \mathrm{~B}$ & $0.37 \mathrm{~A}$ & $1.25 \mathrm{~B}$ & $4.14 \mathrm{~A}$ \\
\hline Sub-surface & $25.3 \mathrm{~B}$ & $0.52 \mathrm{~A}$ & $0.16 \mathrm{~A}$ & $0.36 \mathrm{~B}$ & $1.27 \mathrm{~A}$ & $3.54 \mathrm{~B}$ \\
\hline
\end{tabular}

Values followed by different letters in each column are significantly different by the Scott-Knott test at $5 \%$. Split plot experiment with 216 experimental points, four ages of coffee plantations, three slopes, three sampling locations at two depths, with three replications.

between sampling depths, with higher OM contents in the surface than the sub-surface layer (Table 2). Organic matter content influences almost all other soil physical properties and is mainly responsible for aggregate formation and structural stability in many soils. Organic matter can stabilize the soil structure, making it more resistant to degradation (Cochrane \& Aylmore, 1994) and decreasing bulk density and soil strength (Carter, 2002; Iori et al., 2012a). Hamzaa \& Anderson (2005) summarized the most commonly reported mechanisms by which OM influences soil structure and compactibility: (a) binding the soil mineral particles (Zhang, 1994); (b) reducing aggregate wettability (Zhang \& Hartge, 1992); and (c) influencing the mechanical strength of soil aggregates, which is the measure of coherence of interparticle bonds (Quirk \& Panabokke, 1962).

The values for TP and Ma were higher in soils of the 18-year-old coffee plantation (Table 2) than in the other areas (2, 7 and 33 years old). For Ma, the values were similar for plantation age $(2,7$ and 33 years old). There were no statistical differences between the different slopes analyzed for TP and Ma (Table 2). In the northern mountainous forest of Iran, Najafi et al. (2009) also found that TP was similar on slopes of 9 and $15 \%$. For sampling position, higher TP and Ma were observed in the inter-rows than in the wheel tracks (upper and lower), while upper and lower tracks had similar values (Table 2). The greatest soil structure deformation was detected under the wheel tracks due to machinery traffic in the coffee plantations, while under the, inter-rows, the soil was not disturbed, for being unaffected by agricultural traffic. Gontijo et al. (2008) also found higher TP and Ma in the inter-rows than in the tracks. Similar values in the layers were observed for TP in the surface and sub-surface layers (Table 2). Our results confirmed intense soil compaction along the wheel tracks particularly in the topsoil, owing to higher contact pressure (Balbuena et al., 2000; Hamzaa \& Anderson, 2005).

In the literature, the Ma range of $0.10-0.15 \mathrm{~m}^{3} \mathrm{~m}^{-3}$ is considered critical for plants, i.e., in this range, water infiltration and root aeration of the coffee trees is affected (Cockroft \& Olsson, 1997); plants grow satisfactorily when Ma exceeds the critical values (Kiehl, 1979; Gupta \& Allmaras, 1987). Comparing our results with this widely used critical range, only the 18-year- old plantation had higher Ma values. Comparing the sampling positions, Ma exceeded this critical range in the inter-rows only, while the surface layer and $9 \%$ slope had values below the threshold.

Generally, the ranges of observed micropore (Mi) values in this study were uniform, with a minimal coefficient of variation (Table 1). For the different slopes, Mi values were similar (Table 2) while the plantation age, sampling position and depth factors influenced the responses minimally. The 7-year-old plantation had higher Mi values, followed by the 2 and 18-year-old plantations. The 33-year-old 
plantations had the lowest range of Mi values. The surface had higher Mi values than the sub-surface layer (Table 2), most likely due to transformation of the macropores into micropores as a result of tractor traffic. Dias Junior (2000) showed that pores distribution can be modified by compaction caused by tractor traffic. Gontijo et al. (2008) further showed that the decrease of macropores could be related to a collapse of the soil structure, due to excessive pressure applied on the soil principally on the wheel track. During this process, soil fragments are produced, filling up the macropores and thereby increasing the micropores (Startsev \& McNabb, 2001). The Mi values were higher along the tracks than under the interrows and similarly higher under the lower than the upper track. Gontijo et al. (2008) also found higher Mi values under wheel tracks than in inter-rows, although these authors did not differentiate the lower from the upper wheel track.

We found different mean values of bulk density (BD) in the areas with different ages of coffee plantation; in the 33 year-old-plantation, the $\mathrm{BD}$ values were highest, and consequently highest internal soil strength (Iori et al., 2012b). The lowest BD value was observed under 7 and 18-years-old coffee, followed by the 2 -year-old plantation. The factor slope had no influence on BD (Table 1). On the other hand, sampling position influenced $\mathrm{BD}$, with lowest values under the inter-rows and similar values under the lower and upper tracks. Another factor influencing $\mathrm{BD}$ was the sampling depth, for which values were lowest in the surface layer. The behavior of $\mathrm{BD}$ was similar to that of OM. Ekwue (1990) found a significant relationship between $\mathrm{BD}$ and $\mathrm{OM}$ at the $1 \%$ level. Macrae \& Mehuys (1985) showed that OM reduces $\mathrm{BD}$ by soil dilution and improvement in aggregate stability. Furthermore, in the 33-year-old coffee plantation, the combination of low OM contents and more accumulated traffic increased BD.

An improvement in aggregate stability due to $\mathrm{OM}$ was observed in this study. The highest OM contents in the surface layer also resulted in highest MGD values in this layer (Table 2). Organic matter enhances the aggregation of soil particles, thus higher $\mathrm{OM}$ contents will probably translate to better soil aggregation (Seifert et al., 1998; Ekwue, 1990) resulting in higher MGD. Tisdall \& Oades (1982) observed a positive correlation between OM content and aggregate stability. Boix-Fayos et al. (2001) observed no positive correlation between $\mathrm{OM}$ and microaggregation, but showed that the stability of macroaggregates was positively associated with $\mathrm{OM}$ content. Along the traffic line, the lower end of the track had higher MGD values than the upper track. On slopes, the highest MGD values were observed in the plantation with $3 \%$ slope, followed by those with 15 and $9 \%$ slope. For time since establishment or plantation ages, the MGD values were highest in soil of the oldest plantation (33 years), decreasing in the younger plantations (Table 2).
The relationship between $\mathrm{OM}, \mathrm{BD}$ and $\mathrm{Ma}$ and time since the establishment of the coffee plantation is well fitted by a quadratic regression curve for the three sampling positions studied (Figure 2). At all three sampling positions (lower track, inter-row and upper track) the $\mathrm{OM}$ and $\mathrm{Ma}$ increased with time of establishment up to a certain plantation age beyond which the $\mathrm{OM}$ and $\mathrm{Ma}$ began to decrease with increasing plantation age. Also at all three sampling positions, BD decreased since the establishment of the plantation until a certain age beyond which the BD increased with increasing plantation age. Based on the regression analysis, OM reached a maximum of $42 \mathrm{~g} \mathrm{~kg}^{-1}$ and Ma of $0.20 \mathrm{~m}^{3} \mathrm{~m}^{-3}$ and BD a minimum of $1.13 \mathrm{Mg} \mathrm{m}^{-3}$, at a plantation age of about 16,22 and 18 years, respectively. The lowest and highest $\mathrm{BD}$ and $\mathrm{Ma}$, respectively, were observed in the inter-rows. This is because the inter-rows are not in direct contact with the passing tractor wheels, thus the soil structure was more preserved. For OM, the highest content was observed under the lower track. During the field trials, it was observed that the lower track was always covered with fresh vegetation. Two consequences of the accumulation of vegetation on the soil of the lower track were observed in this study: increased OM contents over the years and less soil structure degradation. On the other hand, the soil of the upper wheel track was bare and therefore more susceptible to soil structure degradation, since $\mathrm{OM}$ accumulation is much lower. The OM contents increased with increasing age of the coffee plantation until 12, 16 and 18 years for lower track, upper track and inter-row, respectively, which may indicate that the OM content increases until a certain plantation age threshold is reached, after which the OM content begins to decrease. In the tropical region where this study was conducted, the general trend of high temperature and intense rainfall results in a higher rate of microbial activity, leading to the rapid decomposition of soil organic matter (Longo \& Espíndola, 2000). Since OM contents in cultivated areas depend mainly on the rate of residue input and intensity of the OM decomposition process (Rangel et al., 2008), the lower residue input in this old plantation promoted the observed OM decrease.

The linear relation between degree of slope with OM, MGD (aggregate stability) and Mi at the different sampling positions is shown in figure 3 . The behavior of OM, MGD and Mi was similar for the different slopes and sampling positions. The increases in slope degree increased Mi under the inter-row and lower track. On the other hand, OM was lower under the upper track and decreased with increasing slope steepness. This was similarly observed for MGD (aggregate stability) under the upper track. The reason was probably the differential pressure on the inclined plane during tractor traffic, causing higher compaction with increased aggregation of soil particles and consequent organic matter degradation.

Another interaction detected in this study was between the plantation age and soil depth for OM, BD 
and Ma (Figure 4). We observed a similar trend as shown in Figure 2, where the parameter curves reached a peak after around 18 years. After this, OM and Ma decreased while BD increased. The BD in the surface layer was low. For OM and Ma, the values were highest in the surface layer. Organic matter had the most pronounced differences between depths for all studied plantation ages. However, in the first few years ( 2 and 7 years of establishment), BD changed little, but differences increased with the plantation age. On the other hand, the differences in Ma were greater between the depths in the first few years of cultivation. In areas with 33-year-old trees, however, the results were the same in both layers (surface and sub-surface). As the establishment time of the coffee plantation increased, the soil physical properties varied more, which could be attributed to a residual effect on the soil layers due to accumulating traffic effects, resulting in degradation of the soil structure. This had been similarly reported by Wood et al. (1993) and Silva et al. (2006). Martins et al. (2012) also found similar results for the physical behavior of soil in coffee plantations with different ages. Our result showed that the percentage of compacted soil samples increases with the age of the coffee plantation.

Table 3 presents the results of the interaction between sampling position and depth for OM, TP, Ma and BD. For OM, some differences between depths were observed for all sampling positions. When we further analyzed the behavior of OM at each depth, we observed marked differences between the sampling positions. We observed highest $\mathrm{OM}$ contents under the lower track followed by inter-row and upper track in the surface layer. On the other hand, in the subsurface layer the OM contents were higher under the tracks and lowest under the inter-row. The higher $\mathrm{OM}$ contents under the lower track could be possibly explained by rapid vegetation growth, as earlier discussed. The values of BD were also similar between depths, under the lower track and upper track, but in the inter-row the differences in BD were significant at both depths. There was possibly some uniformity in stress distribution at both depths along the track and at the other sampling positions as observed in the $\mathrm{BD}$ values. The topsoil had lower Ma values than the sub-surface under both tracks, while the inter-
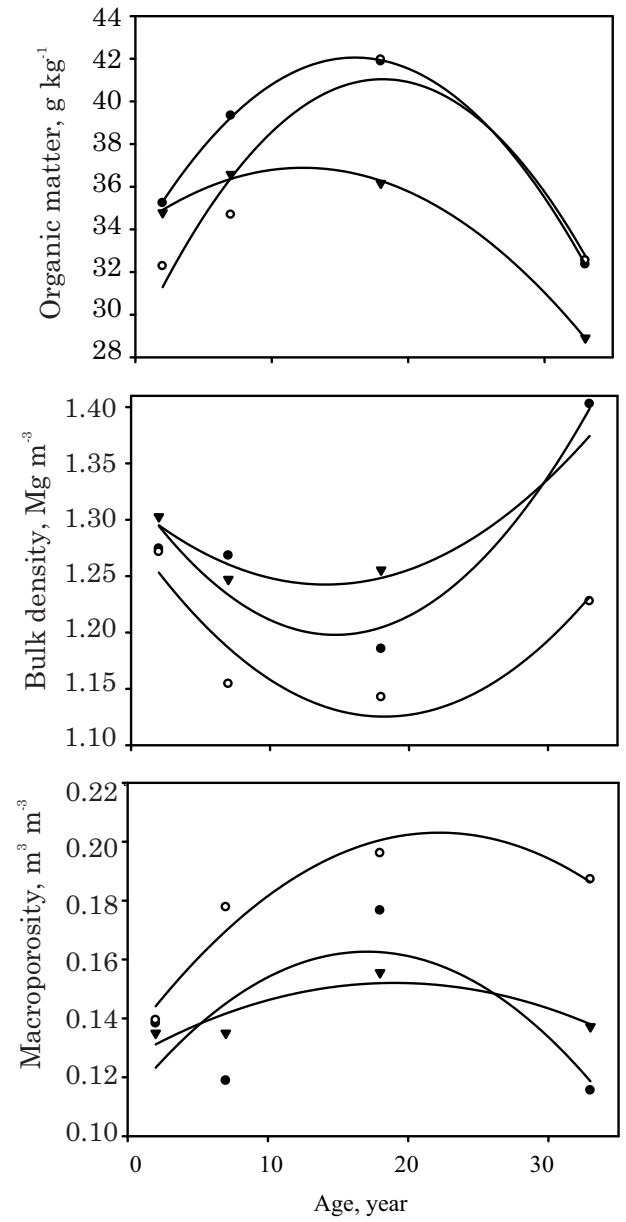

$\mathrm{U} \quad \mathrm{OM}=34.066424+0.458924$ Age $-0.018665 \mathrm{Age}^{2} \mathrm{R}^{2}=0.99 * *$

I $\mathrm{OM}=28.72375+1.358851$ Age $-0.037478 \mathrm{Age}^{2} \mathrm{R}^{2}=0.92^{* *}$

L $\mathrm{OM}=33.242248+1.094802$ Age $-0.033996 \mathrm{Age}^{2} \mathrm{R}^{2}=0.99 * *$

$\mathrm{U} \quad \mathrm{BD}=1.314136-0.010225$ Age $+0.000365 \mathrm{Age}^{2} \quad \mathrm{R}^{2}=0.97 *$

I $\quad \mathrm{BD}=1.286636-0.017704$ Age $+0.000489 \mathrm{Age}^{2} \quad \mathrm{R}^{2}=0.85^{* *}$

L $\quad$ BD $=1.327401-0.017618$ Age +0.000599 Age $^{2} R^{2}=0.92^{* *}$

$\mathrm{U} \quad \mathrm{Ma}=-0.12599+0.002738$ Age $-0.000072 \mathrm{Age}^{2} \quad \mathrm{R}^{2}=0.76^{*}$

I $\mathrm{Ma}=-0.131875+0.00641$ Age $-0.000144 \mathrm{Age}^{2} \quad \mathrm{R}^{2}=0.94^{* *}$

L $\mathrm{Ma}=-0.112099+0.005921$ Age $-0.000173 \mathrm{Age}^{2} \mathrm{R}^{2}=0.52^{* *}$

Figure 2. Effect of the interaction between age and sampling position on organic matter, bulk density and macroporosity (data are means of all three slopes and two depths). $\checkmark$ Upper track (U), o Inter-row (I) and • Lower track $(\mathrm{L})$. 




Figure 3. Effect of the interaction between slope and sampling position on organic matter, aggregate stability by mean geometric diameter and microporosity (data are means of all four ages at two depths). $\nabla$ Upper track (U), o Inter-row (I) and • Lower track (L).

row had similar Ma values at both depths. In the surface layer, Ma was lower than in the sub-surface under both tracks, whereas Ma values in the interrow were similar at both depths.

Our result indicated that most of the investigated variables had a quadratic relationship with the age (time since establishment) of the coffee plantation. We observed that the youngest and oldest plantations had worst soil physical properties. During the early stages of the establishment of the coffee plantation (0-2 years), the impact of soil disturbance by tillage prior to the establishment of the coffee plantation (Iori et al., 2013) is still evident on the soil structure. On the other hand, the physical property of the oldest coffee plantation (33 years) was remarkably altered by accumulated traffic and lower soil organic matter content. The traffic of machinery and equipment particularly on the steep terrains i.e. $\geq 9 \%$ (Figure 1) promoted significant changes in soil physical properties at the three sampling positions. At these field slopes, more slippage of the tires of the machinery can occur, with negative impacts on the soil. Under the upper track physical alterations were more intense than at the other sampling positions, because in the upper track slippage was higher and $\mathrm{OM}$ content lower. The tire slippage can be attributed to the greater weight transfer resulting in a lateral shift of the center of gravity, due to the increased lateral inclination of the track (Khoury Junior et al., 2009), causing the loss of the tire-ground contact. The contact loss is expected at higher field slopes (Leite et al., 2011). The traffic of machines and equipment in coffee rows on flatter terrain will be less affected by slippage, consequently avoiding soil degradation.

\section{CONCLUSIONS}

1. Results from this study showed that the time since the establishment of the coffee plantation (plantation age) and the sampling position (upper track, interrow or lower track) had the strongest effects on the soil physical properties and the organic matter. The age of the coffee plantation had a 


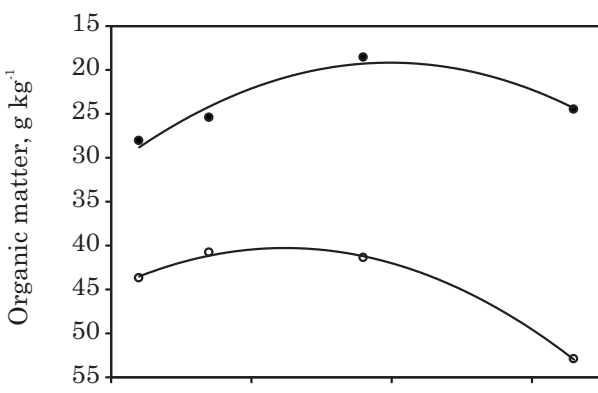

Surf $\mathrm{OM}=38.906367+1.199025$ Age $-0.30148 \mathrm{Age}^{2} \mathrm{R}^{2}=0.94^{* *}$

Sub $\mathrm{OM}=25.115247+0.742693$ Age $-0.029944 \mathrm{Age}^{2} \quad \mathrm{R}^{2}=0.99^{* *}$

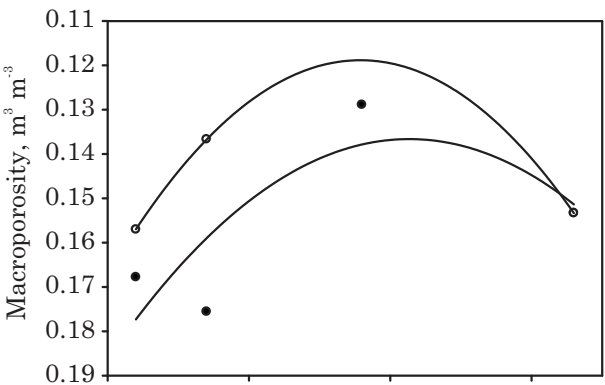

Surf $\mathrm{Ma}=1.305673-0.015735$ Age $+0.000483 \mathrm{Age}^{2} \mathrm{R}^{2}=0.99^{* *}$

Sub $\mathrm{Ma}=1.313111-0.014629$ Age $+0.000484 \mathrm{Age}^{2} \quad \mathrm{R}^{2}=0.97^{* *}$

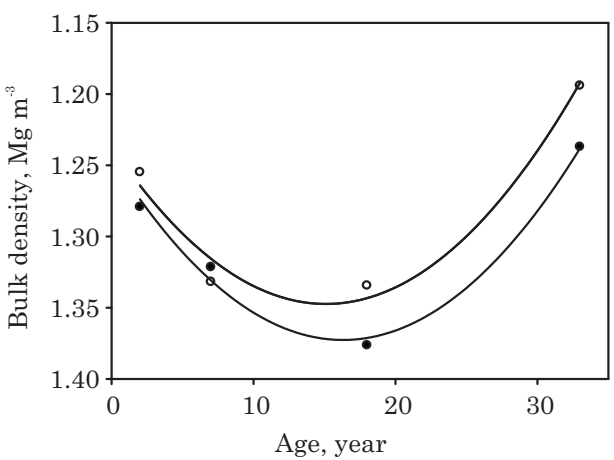

Surf $\mathrm{BD}=0.113836+0.00464$ Age $-0.000109 \mathrm{Age}^{2} \mathrm{R}^{2}=0.64^{* *}$

Sub $\mathrm{BD}=0.132806+0.005406$ Age $-0.000151 \mathrm{Age}^{2} \mathrm{R}^{2}=0.99^{* *}$

Figure 4. Effect of the interaction between age and depth on organic matter, macroporosity and bulk density (data are means of all three slopes and three sampling positions). • Surface layer and $\circ$ Sub-surface.

Table 3. Mean values of organic matter (OM), total porosity (TP), macroporosity (Ma) and bulk density (BD) for different sampling locations and depths in a Red-Yellow Latosol

\begin{tabular}{lccc}
\hline \multirow{2}{*}{ Depth } & \multicolumn{3}{c}{ Sampling location } \\
\cline { 2 - 4 } & Upper track & Inter-row & Lower track \\
\hline \multirow{4}{c}{ Organic matter $\left(\mathrm{g} \mathrm{kg}^{-1}\right)$} \\
Surface & $42.7 \mathrm{Ac}$ & $46.5 \mathrm{Ab}$ & $48.3 \mathrm{Aa}$ \\
Sub-surface & $25.5 \mathrm{Ba}$ & $24.2 \mathrm{Bb}$ & $26.1 \mathrm{Ba}$ \\
& \multicolumn{4}{c}{ Total porosity $\left(\mathrm{m}^{3} \mathrm{~m}^{-3}\right)$} \\
Surface & $0.50 \mathrm{Bb}$ & $0.55 \mathrm{Aa}$ & $0.51 \mathrm{Ab}$ \\
Sub-surface & $0.52 \mathrm{Aa}$ & $0.53 \mathrm{Ba}$ & $0.52 \mathrm{Aa}$ \\
\multicolumn{4}{c}{ Macroporosity $\left(\mathrm{m}^{3} \mathrm{~m}^{-3}\right)$} \\
Surface & $0.12 \mathrm{Bb}$ & $0.18 \mathrm{Aa}$ & $0.12 \mathrm{Bb}$ \\
Sub-surface & $0.16 \mathrm{Aa}$ & $0.17 \mathrm{Aa}$ & $0.15 \mathrm{Aa}$ \\
& \multicolumn{4}{c}{ Bulk density $\left(\mathrm{Mg} \mathrm{m}^{-3}\right)$} \\
Surface & $1.30 \mathrm{Ab}$ & $1.16 \mathrm{Ba}$ & $1.28 \mathrm{Ab}$ \\
Sub-surface & $1.29 \mathrm{Ab}$ & $1.24 \mathrm{Aa}$ & $1.28 \mathrm{Ab}$ \\
\hline
\end{tabular}

Means with the different lower-case letter in each row and with the different capital letter in each column for each soil property are significantly different at the $5 \%$ level by the Scott-Knott test. quadratic relation (curve model) with most studied soil parameters.

2. The soil structure in samples from the interrow was better preserved than in samples from the upper and lower track, and the soil under the lower track was also better preserved than under upper track, mainly due to the differences in accumulated vegetation, moderating the organic matter content.

4. The field slope influenced the organic matter content and some soil physical properties, e.g., microporosity and aggregate stability.

5. Organic matter and aggregate stability varied at the studied depths as affected by the traffic frequency and magnitude.

\section{ACKNOWLEDGEMENTS}

We sincerely appreciate the "Consórcio Brasileiro de Pesquisa e Desenvolvimento do Café CBP\&D/Café" and CAPES, FAPEMIG and CNPq for financial support for the research. 


\section{LITERATURE CITED}

BALBUENA, R.H.; TERMINIELLO, A.M.; CLAVERIE, J.A.; CASADO, J.P. \& MARLATS, R. Soil compaction by forestry harvester operation. Evolution of physical properties. R. Bras. Eng. Agríc. Amb., 4:453-459, 2000.

BLAKE, G.R. \& HARTGE, K.H. Bulk density. In: KLUTE, A., ed. Methods of soil analysis. 2.ed. Madison, ASA/ SSSA. 1986b. Part 1. p.363-375.

BLAKE, G.R. \& HARTGE, K.H. Particle density. In: KLUTE, A., ed. Methods of soil analysis. 2.ed. Madison, ASA/ SSSA, 1986a. Part 1. p.377-382.

BOIX-FAYOS, C.; CALVO-CASES, A.; IMESON, A.C. \& SORIANO-SOTO, M.D. Influence of soil properties on the aggregation of some Mediterranean soils and the use of aggregate size and stability as land degradation indicators. Catena, 44:47-67, 2001.

BRASIL. Ministério da Agricultura. Vegetal: Culturas - Café. 2012. Available at: <http://www.agricultura.gov.br/>. Accessed Oct. 30, 2012.

CARTER, M.R. Soil quality for sustainable land management: Organic matter and aggregation interactions that maintain soil functions. Agron. J., 94:38-47, 2002.

COCHRANE, H.R. \& AYLMORE, L.A.G. The effects of plant roots on soil structure. In: WESTERN AUSTRALIAN SOIL SCIENCE CONFERENCE. Soils "94", 3., Busselton. 1994. Proceedings... Busselton: WA Branch, 1994. p.207-212.

COCKROFT, B. \& OLSSON, K.A. Case study of soil quality in south-eastern Australia: Management of structure for roots in duplex soils. In: GREGORICH, E.G. \& CARTER, M.R., eds. Soil quality for crop production and ecosystem health developments in soil science. New York, Elsevier, 1997. p.339-350.

DAY, P.R. Particle fractionation and particle size analysis. Am. Soc. Agron., 1:545-566, 1965.

DIAS JUNIOR, M.S. Compactação do solo. In: NOVAIS, R.F.; ALVAREZ V., V.H. \& SCHAEFER, C.E.G.R., eds. Tópicos em ciência do solo. Viçosa, MG, Sociedade Brasileira de Ciência do Solo, 2000. v.1. p.55-94.

EKWUE, E.I. Organic-matter effects on soil strength properties. Soil Till. Res., 16:289-297, 1990.

EMPRESA BRASILEIRA DE PESQUISA AGROPECUÁRIA - EMBRAPA. Centro Nacional de Pesquisas de Solos. Manual de métodos de análises do solo. 2.ed. Brasília, Produção de Informação, 1997. 212p.

EMPRESA BRASILEIRA DE PESQUISA AGROPECUÁRIA - EMBRAPA. Centro Nacional de Pesquisas de Solos. Sistema brasileiro de classificação de solos. 2.ed. Rio de Janeiro, Embrapa Solos, 2006. 306p.

FERREIRA, D. Manual do sistema SISVAR para análises estatísticas. Lavras, Universidade Federal de Lavras, 2000. 66p.
GONTIJO, I.; DIAS JUNIOR, M.S.; GUIMARÃES, P.T.G. \& ARAÚJO JÚNIOR, C.F. Atributos físico-hídricos de um Latossolo de cerrado em diferentes posições de amostragem na lavoura cafeeira. R. Bras. Ci. Solo, 32:2227-2234, 2008.

GUPTA, S.C. \& ALLMARAS, R.R. Models to access the susceptibility of soil to excessive compaction. Adv. Soil Sci., 6:65-100, 1987.

HAMZAA, M.A. \& ANDERSON, W.K. Soil compaction in cropping systems. A review of the nature, causes and possible solutions. Soil Till. Res., 82:121-145, 2005.

IORI, P.; DIAS JÚNIOR, M.S. \& SILVA, R.B. Resistência do solo à penetração e ao cisalhamento em diversos usos do solo em áreas de preservação permanente. Biosci. J., 28:185-195, 2012a.

IORI, P.; SILVA, R.B.; DIAS JÚNIOR, M.S. \& LIMA, J.M. Pressão de preconsolidação como ferramenta de análise da sustentabilidade estrutural de Cambissolo Háplico, Argissolo Amarelo e Gleissolo Háplico em Registro, SP. R. Bras. Ci. Solo, 36:1083-1091, 2012b.

IORI, P.; DIAS JUNIOR, M.S.; AJAYI, A.E.; GUIMARÃES, P.T.G.; PAIS, P.S.M. \& ANDRADE, M.L.C. Comparison of field and laboratory models of the load bearing capacity in coffee plantations. Ci. Agrotec., 37:130-137, 2013.

JAMSHIDI, R.; JAEGER, D.; NOSRATOLAH, R. \& TABARI, M. Influence of two ground-based skidding systems on soil compaction under different slope and gradient conditions. Intern. J. For. Eng., 19:9-16, 2008.

KHOURY JUNIOR, J.K.; SOUZA, C.M.A.; RAFULL, L.Z.L. \& VARELLA, C.A.A. Simulação da estabilidade de tratores agrícolas $4 \times 2$. Bragantia, 68:257-267, 2009 .

KIEHL, E.L. Manual de edafologia. São Paulo, Ceres, 1979. 262 p.

KRAG, R.; HIGGINGBOTHAM, K. \& ROTHWELL, R. Logging and soil disturbance in southeast British Columbia. Can. J. For. Res., 16:1345-1354, 1986.

LEITE, F.; SANTOS, J.E.D.; LANÇAS, K.P. \& LEITE JÚNIOR, J.B. Evaluation of tractive performance of four agricultural tractors in laterally inclined terrain. Eng. Agríc., 31:923-929, 2011.

LONGO, R.M. \& ESPÍNDOLA, C.R. C-orgânico, N-total e substâncias húmicas sob influência da introdução de pastagens (Brachiaria sp.) em áreas de Cerrado e Floresta Amazônica. R. Bras. Ci. Solo, 24:723-729, 2000.

MACRAE, R.J. \& MEHUYS, G.R. The effect of green manuring on the physical properties of temperate-area soils. In: STEWART, A.B., ed. Advances in soil science. New York, Springer, 1985. p.71-94.

MARTINS, P.C.C.; DIAS JUNIOR, M.S.; ANDRADE, M.L.C. \& GUIMARÃES, P.T.G. Compaction caused by mechanized operations in a Red- Yellow Latosol cultivated with coffee over time. Ci. Agrotec., 36:391398, 2012. 
MIRANDA, E.E.V.; DIAS JUNIOR, M.S.; GUIMARÃES, P.T.G.; PINTO, J.A.O.; ARAUJO JUNIOR, C.F. \& LASMAR JUNIOR, E. Efeito do manejo e do tráfego nos modelos de sustentabilidade da estrutura de um Latossolo Vermelho cultivado com cafeeiros. Ci. Agrotec., Edição Especial:1506-1515, 2003.

NAJAFI, A.; SOLGI, A. \& SADEGHI, S.H. Soil disturbance following four wheel rubber skidder logging on the steep trail in the north mountainous forest of Iran. Soil Till. Res., 103:165-169, 2009.

QUIRK, J.P. \& PANABOKKE, C.R. Incipient failure of soil aggregates. J. Soil Sci., 13:60-70, 1962.

RANGEL, O.J.P.; SILVA, C.A.; GUIMARÃES, P.T.G.; MELO, L.C.A. \& OLIVEIRA JUNIOR, A.C. Carbono orgânico e nitrogênio total do solo e suas relações com os espaçamentos de plantio de cafeeiro. R. Bras. Ci. Solo, 32:2051-2059, 2008.

SCHALLER, F.W. \& STOCKINGER, K.R. A comparison of five methods for expressing aggregation data. Soil Sci. Soc. Am. J., 17:310-313, 1953.

SEIFERT, N.; BETZ G.; LOPEZ ENCUENTRA, A.; CAMMERAAT, L.H. \& IMESON, A.C. Deriving indicators of soil degradation from soil aggregation studies in southeastern Spain and southern France. Geomorphology, 23:307-321, 1998.
SILVA, A.R.; DIAS JUNIOR, M.S.; GUIMARÃES, P.T.G. \& ARAÚJO JÚNIOR, C.F. Modelagem da capacidade de suporte de carga e quantificação dos efeitos das operações mecanizadas em um Latossolo Amarelo cultivado com cafeeiros. R. Bras. Ci. Solo, 30:207-216, 2006.

SILVA, R.B.; LANÇAS, K.P.; MIRANDA, E.E.V.; SILVA, F.A.M. \& BAIO, F.H.R. Estimation and evaluation of dynamic properties as indicators of changes on soil structure in sugarcane fields of Sao Paulo State Brazil. Soil Till. Res., 103:265-270, 2009.

STARTSEV, A.D. \& McNABB, D.H. Skidder traffic effects on water retention, pore-size distribution, and van Genuchten Parameters of Boreal forest soils. Soil Sci. Soc. Am. J., 65:224-231, 2001.

TISDALL, J.M. \& OADES, J.M. Organic matter and waterstable aggregates in soils. J. Soil Sci., 33:141-163, 1982.

WOOD, R.K.; REEDER, R.C.; MORGAN, M.T. \& HOLMES, R.G. Soil physics properties as affected grain cart traffic. Trans. Am. Soc. Agric. Eng., 36:11-14, 1993.

ZHANG, H. \& HARTGE, K.H. Effect of differently humified organic matter on the aggregate stability by reducing aggregate wettability. J. Plant Nutr. Soil Sci., 155:143149, 1992.

ZHANG, H. Organic matter incorporation affects mechanical properties of soil aggregates. Soil Till. Res., 31:263-275, 1994. 